\title{
Notes on contributors
}

Janet Beer is Dean of Humanities and Social Science at Manchester Metropolitan University. Her research interests are late nineteenth-/early twentieth-century American women writers and contemporary Canadian fiction. She is the author of Edith Wharton: Traveller in the Land of Letters (1990), Kate Chopin, Edith Wharton and Charlotte Perkins Gilman: Studies in Short Fiction (1997) and Edith Wharton (2002) as well as a wide range of reviews and essays.

Bridget Bennett is Senior Lecturer in the School of English, University of Leeds. Her books include an edited book Ripples of Dissent (1996), The Damnation of Harold Frederic (1997) and a jointly edited book (with Jeremy Treglown) Grub Street to the Ivory Tower (1998). She is currently working on a book on nineteenth-century American spiritualism.

Alison Easton is Senior Lecturer in English and a former Director of the Institute for Women's Studies at Lancaster University. She is author of The Making of the Hawthorne Subject, and essays on nineteenth-century American women writers and class relations. She has edited the Penguin Sarah Orne Jewett, The Country of the Pointed Firs and Other Stories, and the Macmillan New Casebook, Angela Carter, and is co-editor of Women, Power and Resistance: An Introduction to Women's Studies. She also published work on gender and nation (in relation to Scotland), and on African-American and Caribbean women writers. She is now engaged on a book on Jewett and social class.

Richard J. Ellis is Professor of English and American Studies at the Nottingham Trent University. He currently edits Comparative American Studies (Sage). His most recent book is a study of the novels of Jack 
Kerouac, Liar! Liar!: Jack Kerouac - Novelist (1999). In 1998 he edited the first modern edition of Harriet Wilson's Our Nig. He has published widely on African-American and contemporary American fiction and on little magazines as a cultural field.

Anne-Marie Ford has just completed a PhD at Manchester Metropolitan University on the work of Elizabeth Barstow Stoddard. In 1998 she was winner of the Marcus Cunliffe travel bursary, awarded by the British Association for American Studies. She is a contributing editor to Key Texts: Documents in the History of American Feminism 1848-1920, to be published by Routledge.

Kate Fullbrook is Professor of Literary Studies and Associate Dean in the Faculty of Humanities at the University of the West of England. She is the author of Katherine Mansfield (1986), Free Women: Ethics and Aesthetics in Twentieth-Century Women's Fiction (1990), and, with Edward Fullbrook, Simone de Beauvoir and Jean-Paul Sartre: The Remaking of a Twentieth-Century Legend (1993) and Simone de Beauvoir: A Critical Introduction (1998). In addition, she has published many articles and reviews. Her major interests are in twentieth-century fiction, American literature, and literature and ethics.

Ann Heilmann is Senior Lecturer in English at the University of Wales Swansea, where she teaches nineteenth-century literature and women's writing. She is the author of New Woman Fiction: Women Writing FirstWave Feminism (2000) and the general editor of Routledge's History of Feminism series. She has edited two anthology sets, The Late-Victorian Marriage Question (1998) and (with Stephanie Forward) Sex, Social Purity and Sarah Grand (2000) and a special issue on the New Woman (for Nineteenth-Century Feminisms). A collection of essays on Feminist Forerunners: Womanism and Feminism in the Early Twentieth Century (Pandora) is forthcoming, and she is now working on a special suffrage issue (for Women's History Review) and a book on New Woman Strategies for Manchester University Press.

Avril Horner is Professor of English at Kingston University and formerly Director of the European Studies Research Institute at the University of Salford. Her research interests and publications focus on twentiethcentury literature and, in particular, on modern poetry, women's writing and the Gothic. She is the editor of European Gothic: A Spirited Exchange, 
1760-1960 (2002). She is the co-author, with Sue Zlosnik, of Landscapes of Desire: Metaphors in Modern Women's Fiction (1990) and Daphne du Maurier: Writing, Identity and the Gothic Imagination (1998). They have also published a number of articles and book chapters on Gothic writing. She is currently working, with Sue Zlosnik, on Gothic and the Comic Turn, to be published by Palgrave.

Katherine Joslin is the author of Edith Wharton in Macmillan's Women Writers Series and co editor of Wretched Exotic: Essays on Edith Wharton in Europe. Her scholarly work includes essays on Willa Cather, Kate Chopin, Theodore Dreiser, George Sand and Emile Zola. Joslin is a Professor of English at Western Michigan University, where she has received the Alumni Teaching Excellence Award and is the director of an interdisciplinary programme in American Studies. Over the past three years, she has directed a Fulbright Summer Institute in the Study of the United States for International Educators. Joslin is currently completing a literary biography of Jane Addams that considers her social work in the context of her several books on urban culture and global peace.

Susan Manning is Grierson Professor of English Literature at the University of Edinburgh. Her primary research interests lie in the field of Scottish-American literary relations, the subject of her book The PuritanProvincial Vision (1990). A second transatlantic study, Fragments of Union, was published by Palgrave in 2001. She has edited the works of Henry Mackenzie (including a new edition of Julia de Roubigné published by Tuckwell Press in 1999), Walter Scott's Quentin Durward, Washington Irving's The Sketch-Book of Geoffrey Crayon, Gent., Hector St John de Crèvecoeur's Letters from an American Farmer and Nathaniel Hawthorne's The Marble Faun OUP, 2002). She has also published articles on a variety of Scottish and American Enlightenment texts and topics.

Carolyn Masel studied at the University of Melbourne, the University of Toronto and the University of Essex, before becoming a lecturer in American Studies at the University of Manchester. Her special field is modern poetry, particularly the poetry of Wallace Stevens, but she also writes on Canadian and Australian literatures. Her work focuses on poetics, intertextuality, influence, gender and issues in postcolonialism. She has been instrumental in preparing the archives of the Bolton Whitman Fellowship at the John Rylands Library of Manchester and the 
Bolton Central Library for microfilming, and has introduced both microfilmed collections.

Judie Newman is Professor of American Studies, in the School of American and Canadian Studies, University of Nottingham and the author of Saul Bellow and History (1984), John Updike (1988), Nadine Gordimer (1988), The Ballistic Bard: Postcolonial Fictions (1995), Alison Lurie: A Critical Study (2000), plus essays and chapters in some 60 scholarly journals and books, as well as being the editor of Dred: A Tale of the Great Dismal Swamp, by Harriet Beecher Stowe (1992). Works in press include Nadine Gordimer's Burger's Daughter: A Casebook (2003). She is currently working on Nathaniel Hawthorne, The Scarlet Letter: A Sourcebook, for Routledge.

Lindsey Traub is a member of Lucy Cavendish College, University of Cambridge. Formerly Vice-President and College Lecturer in English (1995-2002), she is currently working in California. Her research interests are mainly in nineteenth-century American writing, especially Henry James. She has given and published papers on Henry James, Ralph Waldo Emerson and a variety of American women writers including Margaret Fuller, Louisa May Alcott and Charlotte Perkins Gilman.

Sue Zlosnik is Dean of Arts and Sciences at Liverpool Hope, where she also teaches undergraduate and postgraduate courses in women's writing and the Gothic. Together with Avril Horner she has published Landscapes of Desire (1990) and Daphne du Maurier: Writing, Identity and the Gothic Imagination (1998). As well as presenting conference papers and writing essays and articles together, they are working on Gothic and the Comic Turn, to be published by Palgrave. As a solo scholar, Sue Zlosnik works on Victorian writing. 